\title{
Italy: A foreign traveller
}

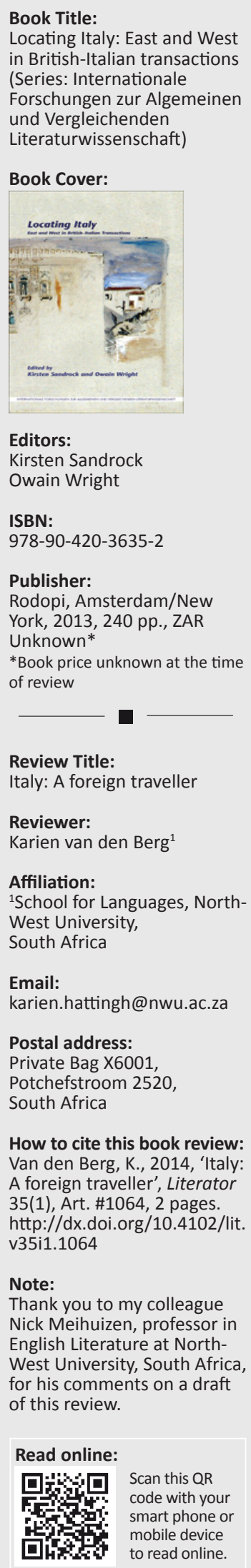

The collection of essays that make up Locating Italy places and displaces Italy in terms of East and West. This volume in a series which examines cross-cultural transactions between Britain and Italy, in a sense comes to resemble the object of investigation. One tries to form a specific picture of the main topic as one progress from the one essay to the next. The diverse viewpoints from which Italy and its role in cultural transactions between East and West are investigated, however, weave a colourful tapestry open to interpretation, rather than painting a detailed portrait of it. Each essay places and displaces Italy in a particular cultural dimension, be it language, literature, art, history or politics. The title of this review was inspired by Martin Stannard's essay, 'East meets West', included in the present collection (p. 169). The collection addresses the theme of cross-cultural transactions in four parts, viz. 'Introduction', 'Painted art as intercultural medium', 'Occident and Orient in British-Italian literature' and 'Intercultural translations in language transactions'.

The collection is introduced as an investigation of the 'ambiguous perceptions of Italy as a country situated at the crossroads of numerous cultural spaces', and it aims to 'dislocate conventional images of Italy and Great Britain as well as of the Occident and Orient as regions in our cultural imagination' (pp. 10-11). This is achieved through insights from a variety of theoretical and interdisciplinary fields. The interaction between the different essays comes to represent the intercultural, linguistic, political and historical and symbolic activity and interaction that surround Italy.

Each essay is a piece of a puzzle that in the end, one feels, may help to locate Italy, as if on a map. But on finishing the volume one is left with the sense of looking at a number of partly built puzzles. These provide glimpses of the 'uncertain locations' (p. 10) which Italy has occupied. They don't quite fit into each other perfectly but by looking at them all one is able to form a sense of the bigger picture. This constellation of essays speaks to the seemingly elusive position and nature of Italy, whilst emphasising its being the epitome of cross-cultural interaction between West and East. The fact that one is left unable to pinpoint where or what Italy reinforces its being a dynamic and multi-cultural nexus of activities.

In her essay 'Theory and practice of translation between East and West', Carla Dente says that:

$[t]$ his work of revision can only be done through the investigation of the disparate dimensions of Eastern cultures in their relationships with Western ones, which have very often led to enlightening considerations in which Eastern cultures have been perceived in the West and on the impact that they have had on some artists. (p. 185)

The collection of essays accomplishes exactly this in regard to Italy. Whilst seemingly being neither in the West nor East, Italy is simultaneously both. It is the 'othered self'. In his essay on English and Italian translation, Jean-Jacques Lecercle does not consider 'othering' to be a means of claiming an identity, and neither does he relate it to a communitarian view in terms of nationality, religion, ethnicity or politics. Othering for him concerns the spaces in between cultures and languages (p. 30). Italy is investigated as a 'space between' Britain - embodying Western culture - and Eastern countries, and cultures, such as that of China. In other words Italy is investigated as the portal between the Occident and the Orient.

Owain Wright explores the historical-political distance between Italy and Britain in terms of Italy's being an apprentice to the British and French as far as political development is concerned, whilst continuously being orientalised by these Western models. The ideological decolonisation of the East is also a recurring theme. Ting Zheng explores China as the 'Other' culture, invented by Europeans. West can only be West if juxtaposed against East. The boundaries between them are cultural and dynamic, not geographical (p. 65). The image that the West has of the East is not based on reality, but is 'rather linked to perceptions of China as a cultural Other' (p. 72).

Copyright: (C) 2014. The Authors. Licensee: AOSIS OpenJournals. This work is licensed under the Creative Commons Attribution License. 
Zheng's notion of the 'Other' being a creation rather than a reality seems applicable to the image of Italy as neither Eastern nor Western, but both. This is the image of Italy that evolves when looking at the partly built puzzles mentioned earlier: an ever-shifting yet consistent one, tinted by the cultural lenses we cannot escape wearing (p. 72). To draw on Dente's reference to Bollettieri Bosinelli's idea of translation, this collection shows that Italy has become the site of 'transfer ... innovation and continuous negotiation', whilst it constructs 'a tradition which implicates a certain continuity with the past, sometimes even an opportunely selected historical past' (p. 187). Images of Italy are not necessarily based on reality, but rather on everything we imagine it to be.

Why then is it important to study these images that the collection of essays presents? Zheng's reference to Mackerras (p. 72) perhaps summarises the issue best: 'Images are an important area of study because they bear on how people of one culture perceive and relate to those of another'. Through a kaleidoscope of theoretical perspectives, this edition reveals the multi-faceted nature of East-West transactions on various plains and thus manages to relocate Italy more clearly - not as either East or West, but as neither and both simultaneously.

This collection of essays will serve a variety of interests, as each essay could be valued on its own and also applied to studies in particular (inter)disciplinary fields. The work as a whole may interest scholars working particularly on notions linked to cultural interactions, East and West, and the notions of Self and Other. The collection therefore is of interest to scholars in the philosophies and theories of both literature and linguistics, translation, history, politics and art. 